\title{
RADICAIS, RACIAIS, RACIONAIS a grande fratria do rap na periferia de São Paulo
}

\author{
Maria Rita Kehl \\ Psicanalista. Autora de A mínima diferença $e$ Deslocamentos do feminino
}

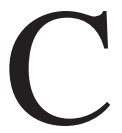

omício do Partido dos Trabalhadores, dia 1ํ de maio de 1999. Tem mais gente do que no ano passado, ou retrasado, mas a diferença não é muito significativa. $\mathrm{O}$ que chama a atenção é a presença de um outro tipo de gente, um "público" diferente da militância petista que já se pode chamar de tradicional, 18 anos depois. São jovens das periferias de São Paulo. A caracterização é clara. Olha-se para eles e se vê que não vieram dos sindicatos, das comunidades católicas, da base organizada de alguns deputados, da militância feminista. Esta moçada usa boné, bermudas largas, moletons imensos, cabelo raspado e óculos escuros. São escuros também, a grande maioria. Estão atentos, um pouco tensos, impacientes, mas nada agressivos. Escutam os discursos (sempre os mesmos, sempre chatos, com exceção das falas vivas do Lula e do Vicentinho), aplaudem, vaiam, repetem algumas palavras de ordem. O clima é pacífico e ordeiro, contrariando preconceitos da classe média branca. Alguns garotos sobem nas janelas do prédio dos Correios para ver melhor; um vitrô abre sozinho, pode-se presentir uma invasão, mas não: os próprios meninos se encarregam de fechar o vidro e continuam equilibrados perigosamente, assistindo a tudo lá do alto.

Quando o animador do comício anuncia a apresentação de alguns grupos de rap, encerrando com os Racionais $M C$ 's, dá para entender a presença da moçada: são os manos. O grande exército dos fãs dos Racionais. Vale falar em $f a \tilde{s}$, no caso deles? Não, com certeza deve haver um termo que indique outro tipo de interação entre a multidão de jovens pobres e os grupos de rap que os representam. É como se cada um deles se considerasse um rapper em potencial, capaz de contar sua vida no ritmo repetitivo e opressivo, nas rimas obrigatórias, às vezes preciosas, às vezes brutais, executando a dança que não autoriza alegria nenhuma, sensualidade nenhuma - disto que nasceu na periferia de algumas cidades americanas como rhythm and poetry e se espalhou pelo Brasil, partindo de São Paulo, é claro: a mais opressiva das cidades brasileiras.

Há 17 anos, a grande festa petista de encerramento da campanha da primeira candidatura do Lula em 1982, daquela vez ao governo de São Paulo, contou com a presença estranha, espontânea, não necessariamente politizada, mas talvez em busca de alternativas, de vários punks da periferia. Sem liderança, desorganizados, os punks fizeram um certo "turismo revolucionário" em volta do PT, que não sabia o que fazer com eles. Seis anos depois, num melancólico e esvaziado 1º de maio de 1988 na praça da Sé, via-se um grupo de punks, já então aderidos a um patético neonazismo, cruzar a praça em atitude ameaçadora, procurando briga. Viraram inimigos da esquerda, truculentos, racistas. Buscaram reconhecimento - isto que todo jovem busca, mas que os pobres precisam lutar muito mais para obter - identificando-se com o opressor. Arrogância, racismo, violência física; os punks marcaram sim sua presença na cidade, mas não foram capazes de superar a condição subjetiva de sua alienação. Tudo o que conseguiram fazer foi passar adiante, para cima de outros garotos ainda mais frágeis do que eles, a humilhação que se recusavam (com razão) a sofrer.

Agora é diferente. A esquerda talvez ainda não saiba o que fazer, ou o que propor, para os milhares de rappers 
que, liderados pelo Mano Brown, parecem interessados em radicalizar um discurso contundente de oposição. Mas os "manos" têm uma idéia um pouco mais precisa de sua revolução, a começar pelas armas: sua palavra em primeiro lugar. Em seguida, sua "consciência", sua "atitude" expressões empregadas insistentemente nas letras dos Racionais, e que em termos gerais significam: orgulho da raça negra e lealdade para com os irmãos de etnia e de pobreza. Sabem para quem estão falando, e sabem sobretudo de onde estão falando: "Mil novecentos e noventa e três, fodidamente voltando, Racionais/ usando e abusando de nossa liberdade de expressão/ um dos poucos direitos que um jovem negro ainda tem neste país./ Você está entrando no mundo da informação/ autoconhecimento, denúncia e diversão./ Este é o raio-X do Brasil, seja bem vindo" ("Fim de semana no parque" - Mano Brown e Edy Rock).

Os quatro jovens integrantes do grupo - Mano Brown, Ice Blue, KL Jay e Edy Rock -, apesar das 500 mil cópias vendidas do último $\mathrm{CD}$, Sobrevivendo no inferno, recusam qualquer postura de pop-star. Para eles, a questão do reconhecimento e da inclusão não se resolve através da ascensão oferecida pela lógica do mercado, segundo a qual dois ou três indivíduos excepcionais são tolerados por seu talento e podem mesmo se destacar de sua origem miserável, ser investidos narcisicamente pelo star system e se oferecer como objetos de adoração, de identificação e de consolo para a grande massa de fãs, que sonham individualmente com a sorte de um dia também virarem exceção. Os integrantes dos Racionais apostam e concedem muito pouco à mídia. "Não somos um produto, somos artistas", diz KL Jay em entrevista ao Jornal da Tarde (5/8/98), explicando por que se recusam a aparecer na Globo (uma emissora que apoiou a ditadura militar "e que faz com que o povo fique cada vez mais burro") e no SBT ("Como posso ir ao Gugu se o programa dele só mostra garotas peladas rebolando ou então explorando o bizarro"?). Até mesmo o rótulo de artista é questionado, numa recusa a qualquer tipo de "domesticação". "Eu não sou artista. Artista faz arte, eu faço arma. Sou terrorista" (Mano Brown).

O tratamento de "mano" não é gratuito. Indica uma intenção de igualdade, um sentimento de fratria, um campo de identificações horizontais, em contraposição ao modo de identificação/dominação vertical, da massa em relação ao líder ou ao ídolo. As letras são apelos dramáticos ao semelhante, ao irmão: junte-se a nós, aumente nossa força. Fique esperto, fique consciente - não faça o que eles esperam de você, não seja o "negro limitado" (título de uma das músicas de Brown) que o sistema quer, não justifique o preconceito dos "racistas otários" (título de outra música). A força dos grupos de rap não vem de sua capacidade de excluir, de colocar-se acima da massa e produzir fascínio, inveja. Vem de seu poder de inclusão, da insistência na igualdade entre artistas e público, todos negros, todos de origem pobre, todos vítimas da mesma discriminação e da mesma escassez de oportunidades. Antes dos Racionais, muitos grupos se apresentaram no Anhangabaú neste $1^{\circ}$ de maio. A impressão que se tinha é que eram todos protegidos dos manos mais velhos, que aceitaram tocar sob condição de abrir espaço para os menos conhecidos. Quando um começo de vaia recebeu a apresentação do Apocalypse 16, os meninos não se intimidaram. Com voz de criança, o líder desta banda cujos componentes não aparentam mais do que 14, 15 anos, chamou a atenção da platéia, conclamou à união, à "atitude consciente", lembrou que eram todos manos; calou a vaia e terminou seu pequeno discurso com: "Apocalypse 16, armados de consciência!”- depois tocaram. Sem muito sucesso, mas tocaram.

Os rappers não querem excluir nenhum garoto ou garota que se pareça com eles.

"Eu sou apenas um rapaz latino-americano/ apoiado por mais de cinqüenta mil manos/ efeito colateral que o seu sistema fez", canta Mano Brown, líder dos Racionais ("Capítulo 4, Versículo 3".) À diferença das bandas de rock pesado, não oferecem a seu público o gozo masoquista de ser insultados por um pop-star milionário fantasiado de outsider. A designação "mano" faz sentido: eles procuram ampliar a grande fratria dos excluídos, fazendo da "consciência" a arma capaz de virar o jogo da marginalização. "Somos os pretos mais perigosos do país e vamos mudar muita coisa por aqui. Há pouco ainda não tínhamos consciência disso" (KL Jay).

A que perigo Jay se refere? A julgar por algumas declarações à imprensa e a maior parte das faixas dos CDs dos Racionais, há uma mudança de atitude, partindo dos rappers e pretendendo modificar a auto-imagem e o comportamento de todos os negros pobres do Brasil: é o fim da humildade, do sentimento de inferioridade que tanto agrada à elite da casa grande, acostumada a se beneficiar da mansidão - ou seja: do medo - de nossa "boa gente de cor". "Quando vocês falam com um cara, o que esperam que aconteça depois?" (Raça) - Brown: "Levantar a cabeça, perder o medo e encarar. Se tomar um soco, devolve". "E o que aconteceria (Raça) se todo negro da perife- 
ria agisse assim?" - "O Brasil ia ser um país mais justo". As mensagens dos Racionais para o pessoal que ouve e compra seus CDs são as seguintes: "Gostaria que eles se valorizassem e gostassem de si mesmos" (Mano Brown); "Ideologia e autovalorização" (KL Jay); "Dignidade deve ser o seu lema” (Ice Blue); "Que escutem os Racionais, é lógico; E paz!”(Edy Rock) (entrevista para DJ Sound n.15, 1991).

Eles apelam para a consciência de cada um, para mudanças de atitude que só podem partir de escolhas individuais; mas a autovalorização e a dignidade de cada negro, de cada ouvinte do rap, depende da produção de um discurso onde o lugar do negro seja diferente do que a tradição brasileira indica. Daí a diferença entre os Racionais e outro jovem músico negro, outro Brown, este baiano. "Tem gente que fala que o rap de São Paulo é triste (Raça). O Carlinhos Brown falou que isto é não saber reinar sobre a miséria" - Mano Brown: "Na Bahia os caras têm que esconder a miséria que é pro turista vir, pra dar dinheiro pros caras lá, inclusive o Carlinhos Brown. São Paulo não é um ponto turístico. E esse negócio de reinar sobre a miséria, você não pode é aceitar a miséria. Mas acho válido o que ele faz pela sua comunidade."

Acontece que os Racionais não estão interessados nem em reinar sobre a miséria (o que seria isto? uma forma mais sedutora de dominação?), nem em esconder a miséria para inglês ver. Seu público-alvo não é o turista - são os pretos pobres como eles. Não, eles não excluem seus iguais, nem se consideram superiores aos anônimos da periferia. Se eles excluem alguém, sou eu, é você, consumidor de classe média - "boy", "burguês", "perua", "babaca", "racista otário" - que curtem o som dos Racionais no toca-CD do carro importado "e se sente parte da bandidagem" (KL Jay). Ou seja: não estão vendendo uma fachada de malandragem para animar o tédio dos jovens de classe média.

Assim, fica difícil gostar deles não sendo um(a) deles. Mais difícil ainda falar deles. Eles não nos autorizam, não nos dão entrada. "Nós" estamos do outro lado. Do lado dos que têm tudo o que eles não têm. Do lado dos que eles invejam, quase declaradamente, e odeiam, declaradamente também. Mas, sobretudo, do lado dos que eles desprezam.

Como gostar desta música que não se permite alegria nenhuma, exaltação nenhuma? Como escutar estas letras intimidatórias, acusatórias, freqüentemente autoritárias, embaladas pelo ritmo que lembra um campo de trabalhos forçados ou a marcha dos detentos ao redor do pátio, que os garotos dançam de cabeça baixa, rosto quase escondi- do pelo capuz do moleton e os óculos escuros, curvados, como se tivessem ainda nos pés as correntes da escravidão? Por onde se produz a identificação através de um abismo de diferenças, que faz com que adolescentes ricos ouçam e (por que não?) entendam o que estão denunciando os Racionais, e uma mulher adulta de classe média receba a bofetada violenta do rap não como um insulto mas como um desabafo compartilhado, não como uma provocação pour épater, mas como uma denúncia que a compromete imediatamente com eles?

Se eles não me autorizam, vou ter que forçar a entrada. A identificação me facilita as coisas; aposto no espaço virtual, simbólico, e portanto inesgotável, da fratria e me passo para o lado dos manos, sem esquecer (nem poderia) a minha diferença - é de um outro lugar, do "meu" lugar, que escuto e posso falar dos Racionais MC's. É porque eles falam diretamente não apenas à minha má consciência de classe média esquerdista, mas ao mal-estar que sinto por viver num país que reproduz diariamente, numa velocidade de linha de montagem industrial, a violenta exclusão de milhares de jovens e crianças que, apesar dos atuais discursos neoliberais que enfatizam a competência e o esforço individual, não encontram nenhuma oportunidade de sair da marginalização em que se encontram. Milhares de crianças e jovens cujas vidas correm o risco de ser apenas o "efeito colateral que o seu (meu!) sistema fez" ("Cap. 4, Versículo 3" - Mano Brown). É a capacidade de simbolizar a experiência de desamparo destes milhões de periféricos urbanos, de forçar a barra para que a cara deles seja definitivamente incluída no retrato atual do país (um retrato que ainda se pretende doce, gentil, miscigenado), é a capacidade de produzir uma fala significativa e nova sobre a exclusão, que faz dos Racionais $M C$ 's o mais importante fenômeno musical de massas do Brasil dos anos 90.

\section{A FRATRIA ÓRFÃ}

$60 \%$ dos jovens de periferia sem antecedentes criminais ja sofreram violência policial. A cada 4 pessoas mortas pela polícia, 3 são negras. Nas universidades brasileiras, apenas $3 \%$ dos alunos são negros. A cada 4 horas, um jovem negro morre violentamente em São Paulo. Aqui quem fala é Primo Preto, mais um sobrevivente. Brown, Cap. 4, Versículo 3

Quem prestar atenção nas letras quilométricas do rap, provavelmente vai se sentir mal diante do tom com que são proferidos estes discursos. É um tom que se poderia 
chamar de autoritário, mistura de advertência e de acusação. A voz do cantor/narrador dirige-se diretamente ao ouvinte, ora supondo que seja outro mano - e então avisa, adverte, tenta "chamar à consciência" -, ora supondo que seja um inimigo -, e então, sem ambigüidades, acusa. Diante de uma voz assim tão ameaçadora, de um discurso que nos convida a "trocar uma idéia" mas não troca nada, não negocia nada de seu ponto de vista e de sua posição (posição sempre moral, mas não necessariamente moralista - veremos), cabe ao ouvinte indagar: mas como ele se autoriza? Quem ele pensa que é?

O Brasil é um país que se considera, tradicionalmente, órfão de pai. Não prezamos nossos antepassados portugueses; não respeitamos uma elite governante que não respeita nem a lei, nem a sociedade, nem a si mesma; não temos grandes heróis entre os fundadores da sociedade atual, capazes de fornecer símbolos para nossa auto-estima. Nossa passagem do "estado de natureza" (que é como, erradamente, simboliza-se as culturas indígenas) ao "estado de cultura" não se deu com a chegada de um grupo de puritanos trazendo o projeto de fundar uma comunidade religiosa, como no caso dos Estados Unidos, mas pelo despejo, nessas terras, de um bando de degredados da Coroa portuguesa. Não vieram para civilizar, mas para usufruir e principalmente, usurpar. Pelo menos é assim que se interpreta popularmente, com boa dose de ironia, a chegada dos portugueses ao Brasil. ${ }^{1}$ Fundou-se assim o mito da "pátria-mãe gentil" (que Caetano Veloso acertadamente chamou "mátria", pedindo a seguir: "quero fratria"!) que tudo autoriza, tudo tolera, "tudo dá".

É óbvio que o mito da abundância fácil produziu exploração, concentração de riquezas numa escala que nos coloca em primeiro lugar no ranking da vergonha mundial e miséria. É óbvio que a orfandade simbólica produziu não uma ausência de figuras paternas, mas um excesso de pais reais, abusados, arbitrários e brutais como o "pai da horda primitiva" do mito freudiano. O que falta à sociedade brasileira não é mais um painho mandão e pseudo protetor (vide ACM, Getúlio, Padre Cícero, etc.), mas uma fratria forte, que confie em si mesma, capaz de suplantar o poder do "pai da horda" e erigir um pai simbólico, na forma de uma lei justa, que contemple as necessidades de todos e não a voracidade de alguns.

Mas, numa sociedade acostumada ao paternalismo autoritário, também para as formações fraternas, em sua função criadora de significantes e de cidadania, colocase uma questão: como evitar que, do ato de coragem coletivo que elimina a antiga dominação do pai onipotente e institui um novo pacto civilizatório, produza-se um novo usurpador na figura do herói? Por outro lado, como manter, na ausência do herói concentracionário da fala coletiva (lembrar Roland Barthes: "o mito é uma fala roubada"), um discurso consistente que suporte e legitime as formações sociais produzidas na horizontalidade das relações democráticas? Como sustentar, na expressão de Jacques Rancière, a "letra órfã", as novas formas de linguagem produzidas nas trocas horizontais e que tentam comunicar, de um semelhante a outro, experiências que façam sentido, que produzam valor, que sugiram um "programa mínimo" para uma ética da convivência?

As falas dos Racionais oscilam; passam do lugar comunitário dos manos ao lugar do herói exemplar, escorregando dali para o lugar da autoridade, falando em nome de um "pai" que sabe mais, que pode aconselhar, julgar, orientar. Por que "Racionais"? - perguntou o repórter da revista Raça. Edy Rock responde: "Vem de raciocínio, né? Um nome que tem a ver com as letras, que tem a ver com a gente. Você pensa pra falar." (grifo nosso). Brown: "Naquela época o rap era muito bobo. Rap de enganar, se liga, mano? Não forçava a pensar". Mais adiante, Brown (respondendo a uma questão de por que o rap é político): "Você já nasceu preto, descendente de escravo que sofreu, filho de escravo que sofreu, continua tomando 'enquadro' da polícia, continua convivendo com drogas, com tráfico, com alcoolismo, com todos os baratos que não foi a gente que trouxe pra cá. Foi o que colocaram pra gente. Então não é uma questão de escolha, é que nem o ar que você respira. Então o rap vai falar disso aí, porque a vida é assim."

Vejamos um dos muitos trechos de letras que ilustram esta dupla inscrição do sujeito, que, por um lado, "pensa pra falar" - produz uma fala própria, destacada dos discursos do Outro -, mas, por outro lado, não poderia falar de outra coisa, "porque a vida é assim", ou seja, não confunde sua autonomia pensante e crítica com uma arbitrariedade de referências, como o delírio de auto-suficiência típico da alienação subjetiva das sociedades de consumo. O distanciamento necessário para se pensar antes de falar vem de um mergulho na própria história ("somos descendentes de escravo que sofreu...") e de uma aceitação ativa, não conformista, da própria condição, do pertencimento a um lugar e uma coletividade que, ao mesmo tempo que fortalece os enunciados, recorta um campo a partir de onde o sujeito pode falar, dificultando o escape na direção de fantasias de adesão a fórmulas imaginárias de aliciamento ou de consolação. 
"Eu não sei se eles/ estão ou não autorizados/ a decidir o que é certo ou errado/ inocente ou culpado retrato falado/ não existe mais justiça ou estou enganado? Se eu fosse citar o nome de todos os que se foram/ o meu tempo não daria para falar mais.../ e eu vou lembrar que ficou por isso mesmo/ e então que segurança se tem em tal situação/ quantos terão que sofrer pra se tomar providência/ ou vão dar mais um tempo e assistir a seqüência/ e com certeza ignorar a procedência./ O sensacionalismo pra eles é o máximo/ acabar com delinqüentes eles acham ótimo/ desde que nenhum parente ou então é lógico/ seus próprios filhos sejam os próximos (...) Ei Brown, qual será a nossa atitude?/ A mudança estará em nossa consciência/ praticando nossos atos com coerência/ e a conseqüência será o fim do próprio medo/ pois quem gosta de nós somos nós mesmos/ tipo, porque ninguém cuidará de você/ não entre nessa à toa/ não dê motivo pra morrer/ honestidade nunca será demais/ sua moral não se ganha, se faz/ não somos donos da verdade/ por isso não mentimos/ sentimos a necessidade de uma melhoria/ nossa filosofia é sempre transmitir/ a realidade em si/ Racionais MC's" ("Pânico na zona Sul").

Nos últimos versos de "Júri Racional" o grupo condena um negro "otário" que "se passou para o outro lado", recusando a identificação com os manos em troca da aceitação dos playboys.

"Eu quero é devolver nosso valor, que a outra raça tirou./ Esse é meu ponto de vista. Não sou racista, morou?/ E se avisaram sua mente, muitos de nossa gente/ mas você, infelizmente/ sequer demonstra interesse em se libertar./ Essa é a questão, autovalorização/esse é o título da nossa revolução./ Capítulo 1:/ O verdadeiro negro tem que ser capaz/ de remar contra a maré, contra qualquer sacrifício./ Mas no seu caso é difícil: você só pensa no próprio benefício./ Desde o início, me mostrou indícios/ que seus artifícios são vícios pouco originais/ artificiais, embranquiçados demais./ Ovelha branca da raça, traidor! Vendeu a alma ao inimigo, renegou sua cor" Refrão: "Mas nosso júri é racional, não falha/ por quê? não somos fãs de canalha! Conclusão: "Por unanimidade/ o júri deste tribunal declara a ação procedente/ e considera o réu culpado/ por ignorar a luta dos antepassados negros/ por menosprezar a cultura negra milenar/ por humilhar e ridicularizar os demais irmãos/ sendo instrumento voluntário do inimigo racista./ Caso encerrado".

O viés autoritário desses versos, a nosso ver, tem pelo menos três determinantes. Primeiro, a certeza de que uma causa coletiva está em jogo. Trata-se de estancar o derra- mamento de sangue de várias gerações de negros, de barrar a discriminação sem recusar a marca originária. Nada de abaixar a cabeça, fazer o "preto de alma branca" que a elite sempre apreciou. Trata-se de produzir "melhoria" na vida da periferia. Mas para isto - aí vem a segunda razão - é necessário "transmitir a realidade em si". Isto porque a maior ameaça não vem necessariamente da violência policial, nem da indiferença dos "boys". Vem da mistificação produzida pelos apelos da publicidade, pela confusão entre consumidor e cidadão que se estabeleceu no Brasil neoliberal, que fazem com que o jovem da periferia esqueça sua própria cultura, desvalorize seus iguais e sua origem, fascinado pelos signos de poder ostentados pelo burguês. É aí, dizem as letras de Brown, que ele se perde:

"Você viu aquele mano na porta do bar/ ele mudou demais de uns tempos pra cá/ cercado de uma pá de tipo estranho/ que promete pra ele o mundo dos sonhos./ Ele está diferente, não é mais como antes/ agora anda armado a todo instante/ não precisa mais dos aliados/negociantes influentes estão ao seu lado./ Sua mina apaixonada, linda e solidária/ perdeu a posição, ele agora tem várias... (...) Ascenção meteórica, contagem numérica/ farinha impura, o ponto que mais fatura/ um traficante de estilo, bem peculiar/ você viu aquele mano na porta do bar?" (...) "A lei da selva é assim, predatória/ clic, clec, BUM, preserve sua glória/ transformação radical, estilo de vida/ ontem sossegado, e tal/ hoje homicida/ ele diz que se garante e não tá nem aí/ usou e viciou a molecada daqui'... ("Mano na porta do bar" - Brown e Rock).

Aqui entra a terceira determinação, que justifica que o discurso predominantemente moral dos Racionais não se confunda com moralismo, já que não fala em nome de nenhum valor universal, além da preservação da própria vida. O tom autoritário das letras está avisando os manos: onde reina a "lei da selva" a pena de morte já está instalada, sem juízo prévio. Diante da vida sempre ameaçada, não se pode vacilar.

"Você está vendo o movimento na porta do bar?/ tem muita gente indo pra lá, o que será? /(...) Ouço um moleque dizer, mais um cuzão da lista/ dois fulanos numa moto, única pista/ eu vejo manchas no chão, eu vejo um homem ali/ é natural para mim, infelizmente./ A lei da selva é traiçoeira, surpresa/ hoje você é o predador, amanhã é a presa./ Já posso imaginar, vou confirmar/ me aproximei da multidão e obtive a resposta/ você viu aquele mano na porta do bar?/ ontem ele caiu com uma rajada nas costas"... 
O terror, e não o poder, dá o tom exasperado a essas falas. O crime e a droga são uma tentação enorme, agravada ainda pela falta de alternativas. O rap não oferece, evidentemente, nenhuma saída material para a miséria; também não aposta na transgressão como via de auto-afirmação, como é comum entre os jovens de classe média (exemplo disso é o sucesso do grupo Planet Hemp). Muito menos no confronto direto com a principal fonte de ameaças contra a vida dos jovens, que a julgar pelo rap, é a própria polícia. Conformismo ou sabedoria? Provavelmente um pouco de cada um, se é que se pode considerar conformista o ceticismo dos manos quanto à possibilidade de enfrentamento com as instituições policiais no Brasil. O que o rap procura promover são algumas atitudes individuais fundamentadas numa referência coletiva. "Se eu fosse aquele cara que se humilha no sinal/ por menos de um real, minha chance era pouca/ mas se eu fosse aquele moleque de touca/ que engatilha e enfia o cano dentro de sua boca/ de quebrada, sem roupa, você e sua mina/ um, dois, nem me viu! já sumi na neblina./ Mas não! permaneço vivo, eu sigo a mística/ 27 anos contrariando a estatística (grifo nosso)./ Seu comercial de TV não me engana/ eu não preciso de status, nem fama./ Seu carro e sua grana já não me seduz/ e nem a sua puta de olhos azuis./ Eu sou apenas um rapaz latino-americano/apoiado por mais de cinqüenta mil manos (grifo nosso)/ efeito colateral que seu sistema produz..." (“Capítulo 4, Versículo 3").

\section{FUNÇÃO DO PAI, INVENÇÕES DOS MANOS}

Os "cinqüenta mil manos" produzem um apoio - mas onde está um pai? Qual o significante capaz de abrigar uma lei, uma interdição ao gozo, quando a única compensação é o direito de continuar, "contrariando as estatísticas", a lutar pela sobrevivência? Surpreendentemente, Mano Brown "usa" Deus para fazer esta função. Embora em nenhum momento fale em nome de igreja nenhuma, Deus é lembrado - mas para quê? "Irmão, o demônio fode tudo ao seu redor/ pelo rádio, jornal, revista e outdoor./ Te oferece dinheiro, conversa com calma/ contamina seu caráter, rouba sua alma/ depois te joga na merda sozinho,/ transforma um preto tipo A num neguinho./ Minha palavra alivia sua dor,/ ilumina minha alma, louvado seja o meu Senhor/ que não deixa o mano aqui desandar,/ ah, nem sentar o dedo em nenhum pilantra./ Mas que nenhum filho da puta ignore a minha lei./ (“Capítulo 4, Versículo 3").

Deus é lembrado como referência que "não deixa o mano aqui desandar", já que todas as outras referências ("rádio, jornal, revista e outdoor") estão aí para "transformar um preto tipo A num neguinho". Deus é lembrado como pai cujo desejo indica ao filho o que é ser um homem: um "preto tipo A". Pela primeira vez, fez sentido para mim a frase "Jesus te ama", que vejo freqüentemente colada nos vidros dos carros (embora naqueles casos, a meu ver, o sentido propagandístico, voltado ao aliciamento e à domesticação do outro, predomine sobre o sentido de auto-ajuda da utilização de Deus feita por Mano Brown); pois é preciso que o Outro me ame, para que eu possa me amar. É preciso que o Outro aponte, a partir do seu desejo (que não se pode conhecer, mas a cultura não cessa de produzir pistas para que se possa imaginar), um lugar de dignidade, para que o sujeito sinta-se digno de ocupar um lugar.

Não me atrevo a interpretar a religiosidade pesssoal, íntima, dos componentes do grupo. Mas sugiro que o Senhor que aparece em alguns destes raps (junto com os Orixás! ver "A fórmula mágica da paz" - Mano Brown: "agradeço a Deus e aos Orixás/ parei no meio do caminho e olhei para trás"), além de simbolizar a Lei, tem a função de conferir valor à vida, que para um mano comum "vale menos que o seu celular e o seu computador" ("Diário de um detento", Brown e Jocenir, este último prisioneiro da casa de Detenção de São Paulo). No que depender da lei dos homens, estes jovens já estão excluídos, de fato, até do programa mínimo da Declaração dos Direitos do Homem. A alternativa simbólica moderna, imanente, a Deus, seria "a sociedade" - esta outra entidade abstrata, abrangente, que deveria simbolizar o interesse comum entre os homens, a instância que "quer" que você seja uma pessoa de bem, e em troca lhe oferece amparo, oportunidades e até algumas alternativas de prazer.

A sociedade - temos mais de 200 anos de Iluminismo nas costas! Mas será que o Iluminismo alguma vez falou para a ralé? - é uma instância superior a Deus do ponto de vista da emancipação dos homens, já que existe no reino deste mundo, organizada a partir - supõe-se - das necessidades e acordos estabelecidos entre semelhantes, e maleável na medida das transformações destas necessidades. Mas, do ponto de vista dos manos, a sociedade é hostil ou, no mínimo, indiferente. A sociedade "não se importa", não vai alterar seu sistema de privilégios para incluir e contemplar os direitos deles. A regressão (do ponto de vista filosófico) a Deus faz sentido, num quadro de absurda injustiça social, considerando-se que a outra alternativa é a regressão à barbárie.

Vale lembrar - estarei sendo otimista, interpretando a partir de meu próprio desejo? - que o Deus de Brown não 
produz conformismo, esperança numa salvação mágica, desvalorização desta vida em nome de qualquer felicidade eterna. Deus está lá como referência simbólica, para "não deixar desandar" a vida desses moços nada comportados que falam numa revolução aqui na terra mesmo ("Deus está comigo, mas o revólver também me acompanha." Ice Blue ao JT, s/d) e lembram sempre: "Quem gosta de nós somos nós mesmos" ("Pânico na Zona Sul").

Mas que não se confunda este "gostar de nós" com uma afirmação de auto-suficiência, de um individualismo que só se sustenta (imaginariamente!) nos casos em que é possível se cumprir as condições impostas pela sociedade de consumo - a posse de bens cuja função é obturar as brechas da "fortaleza narcísica" do $e u$, a alienação própria da posição do "senhor", que não lhe permite enxergar sua dependência quanto ao trabalho do "escravo", e a disponibilidade do dinheiro como fetiche capaz de velar, para o sujeito, a consciência de seu desamparo. O mandato "goste de você" emitido pelos Racionais não poderia ser uma incitação ao individualismo mesmo se quisesse, já que estas condições estão muito longe de se cumprir dada a situação de permanente desamparo e falta no real, da vida na periferia - a não ser, é claro, em sua face bárbara, a do tráfico e consumo de drogas.

O traficante representa, nas letras de Brown e Edy Rock, a face bárbara do individualismo burguês: o cara que não está nem aí pra ninguém, que só defende o dele, que não tem escrúpulos em viciar a molecada, expor crianças ao perigo fazendo avião para eles. A outra face é a do otário, o "negro limitado" (título de música - Brown e Rock), a quem falta "postura", "atitude", que se ilude pensando que pode se destacar entre seus semelhantes recusando a raça, etc. "Não quero ser o mais certo/ e sim o mano esperto", responde Brown ao mano "limitado". Mais uma vez, uma postura moral se funda sobre a ameaça extrema do extermínio. O "mano esperto" é o que sabe que a opção da alienação - que na miséria da periferia precisa da droga para se sustentar - está sujeita à pena de morte, à lei da selva da polícia brasileira ou destes capitalistas selvagens que são os donos do tráfico: “A segunda opção é o caminho mais rápido/ e fácil, a morte percorre a mesma estrada, é/ inevitável./ Planejam nossa restrição, esse é o título/ da nossa revolução, segundo versículo/ leia, se forme, se atualize, decore/ antes que racistas otários fardados de cérebro atrofiado/ os seus miolos estourem e estará tudo acabado./ Cuidado!/ O Boletim de Ocorrência com seu nome em algum livro/ em qualquer arquivo, em qualquer distrito/ caso encerrado, nada mais que isso" ("Negro Limitado").
A insignificância da vida, o vazio que nossa passagem pelo mundo dos vivos vai deixar depois de nossa morte nós que apostamos sempre em marcar nossa presença deixando uma obra, uma palavra, uma lembrança imortal -, isto que a psicanálise aponta como a precariedade da condição humana e que um neurótico de classe média precisa trabalhar tanto para suportar, estão dados no dia-a-dia, na concretude da vida no "inferno periférico"(Edy Rock) de onde eles vêm. Portanto, a possibilidade do delírio narcísico-individualista está excluída, a não ser que se encare as consequiências da opção pelo crime. "Não tava nem aí, nem levava nada a sério/ admirava os ladrão e os malandro mais velho/ mas se liga, olhe ao redor e diga/ o que melhorou da função, quem sobrou, sei lá/ muito velório rolou de lá pra cá/ qual a próxima mãe a chorar/ já demorou mas hoje eu posso compreender/ que malandragem de verdade é viver (grifo nosso)/ Agradeço a Deus e aos Orixás/ parei no meio do caminho e olhei para trás"... ("Fórmula Mágica da Paz"- Mano Brown).

A outra opção - a primeira, aliás, nos versos da música "Negro Limitado" - é o apelo ao outro como parceiro na construção de outras referências, na invenção de espaços simbólicos que possibilitem alguma independência em relação à sedução do circuito crime-consumismo-extermínio. Assim, o "goste de você" não soa como comando ao isolamento, a um fechar-se sobre si mesmo como resposta para todos os problemas. Ao contrário, a frase soa como apelo ao outro para que reconheça e valorize a semelhança entre eles.

$\mathrm{O}$ apelo ao reconhecimento é geralmente endereçado ao pai. O irmão, o semelhante, será destinatário deste apelo apenas quando o pai dá as costas? Pensamos que não; o reconhecimento paterno, fundamental para que o sujeito constitua uma certeza imaginária sobre "quem ele é" (para o desejo do pai), pode gerar também um aprisionamento narcísico. O sujeito só começa a se mover de sua posição no triângulo edípico, entre o olhar da mãe que seduz e o do pai que interdita e se oferece à identificação (e ao ideal), quando da entrada de um outro, um irmão (consangüíneo ou não), que abre para a alteridade, para a constatação, em espelho, de sua própria insignificância; mas também para a infinidade de possibilidades subjetivas que se abrem ante a descoberta da semelhança na diferença.

$\mathrm{O}$ outro funciona também como parceiro e cúmplice nas moções de transgressão em relação à interdição paterna - e então, de duas, uma. Ou a interdição não se sustenta mais - pense-se no caso de um pai perverso, por exemplo, capaz de manter uma posição autoritária, mas 
incapaz de simbolizar a lei e sujeitar-se a ela -, e neste caso os irmãos escapam à função paterna, fazendo sua própria versão do desejo do pai (a père-version a que se refere Lacan) e fundando, na delinquiência, uma gangue; ou a lei se mantém cumprindo sua função mínima de interditar o gozo (aos filhos, mas também ao pai!), mas a aliança fraterna possibilita que os sujeitos explorem e ampliem suas margens, relativizando o discurso da autoridade encarnado pela figura do pai real. É a constatação da semelhança na diferença que se dá com a entrada do "pequeno outro", que permite ao sujeito separar a lei simbólica - diante da qual todos se equivalem - da figura real do pai encarnado naquele sujeito frágil, arbitrário, limitado e desejante que, mesmo quando se faça respeitar, é incapaz de apagar as diferenças significantes entre todos os filhos que levam o mesmo nome, o seu nome.

Fizemos esta longa passagem para dizer que a fratria não é convocada a operar só na falta do pai. Mas, quando ninguém nessa vida encarna o pai, quando é preciso apelar ao "Senhor" para imaginar que "alguém" (no eixo vertical da constituição subjetiva) me ama e me proíbe abusos, o reconhecimento entre irmãos se torna essencial. Até mesmo para sustentar a existência deste Deus, aliás, que se não fosse o significante de uma formação simbólica (portanto coletiva), seria o elemento central de um delírio psicótico. Além disso, na falta do reconhecimento de um pai, é a circulação libidinal entre os membros da fratria que produz um lugar de onde o sujeito se vê, visto pelo olhar do(s) outro(s). Prova disto é a grande importância que a criação de apelidos adquire nos grupos de adolescentes, por exemplo, como indicativos de um "segundo batismo", a partir de outros campos identificatórios por onde os sujeitos possam se mover, ampliando as possibilidades estreitas fundadas sobre o traço unário da identificação ao ideal paterno. As identificações horizontais talvez permitam a passagem da ilusão de uma "identidade" (em que o sujeito se acredita idêntico a si mesmo, colado ao nome próprio dado pelo pai) à precariedade das identificações secundárias, a partir de outros lugares que o sujeito vai ocupando entre seus semelhantes, e que o apelido dado pela turma é capaz de revelar.

Quando os Racionais apelam a que os manos se identifiquem com a causa dos negros, estarão propondo um campo identificatório - com sua diversidade de manifestação singulares - ou a produção de uma identidade, com sua camisa-de-força subjetiva? "Gosto de Nelson Mandela, admiro Spike Lee,/ Zumbi, um grande herói, o maior daqui./ São importantes pra mim, mas você ri e dá as cos- tas/ então acho que sei de que porra você gosta:/ se vestir como playboy, freqüentar danceterias/ agradar os vagabundos, ver novela todo dia,/ que merda!/ Se esse é seu ideal, é lamentável/ é bem provável que você se foda muito/ você se autodestrói e também quer nos incluir/ porém, não quero, não vou/ sou negro, não vou admitir!/ De que valem roupas caras, se não tem atitude?/ e o que vale a negritude, se não pô-la em prática?/ A principal tática, herança da nossa mãe África/ a única coisa que não puderam roubar!/ se soubessem o valor que a nossa raça tem/ tingiam a palma da mão pra ser escura também!" ("Júri racional" - Mano Brown). A questão é complicada. Uma vez, indagado sobre sua identificação ao judaísmo, Freud respondeu que se não existisse anti-semitismo, não faria questão nem de circuncidar os próprios filhos; mas diante do preconceito, não tinha outra opção senão a de se afirmar como judeu. Talvez se possa interpretar desta forma a convocação dos Racionais a uma "atitude" que sustente o amor-próprio entre os negros contra o sentimento de inferioridade produzido pela discriminação, o que passa pela afirmação da raça - este significante tão duvidoso, que produz discriminação ao mesmo tempo que indica a diferença.

Mas, quem sabe se possa mesmo ultrapassar esta limitação imaginária, este suporte físico - cor da pele - que produz simultaneamente a identificação e a discriminação racial? Quem sabe a multidão de admiradores dos grupos de rap não estará tentando dizer, como os estudantes parisienses em maio de 68 , quando o governo tentou expulsar Daniel Cohn-Bendit sob a alegação de não ser um cidadão francês: "somos todos judeus alemães"!, e explodir a fronteira da raça pela via das identificações com as formações culturais: somos todos manos negros da periferia? Finalmente, está claro por que posso me autorizar a falar $d e$, ou mais, a falar com, os manos dos Racionais. Pois, se a afirmação dos campos identificatórios (estou recusando propositalmente o termo identidade) não produzir laços sociais, afinidades eletivas que incluam o semelhante na diferença (tornando obsoletos os traços da raça, ou do sexo, por exemplo), há sempre de produzir isolamento entre os grupos e, num sentido ou no outro, discriminação. Que a auto-estima e a dignidade dos rapazes negros da periferia não dependam da aceitação por parte da elite branca, não significa que não produzam outros laços, outras formas de comunicação, inclusive com grupos mais ou menos marginais a esta própria elite. Neste caso, a identificação que começou pela cor da pele, ampliou-se para abrigar outros sentidos: exclusão, indigna- 
ção, repúdio à violência e às injustiças, etc. Não somos "todos" pretos pobres da periferia, mas somos muitos mais do que eles supunham quando começaram a falar.

\section{O CÉU CHEIO DE PIPAS}

Caralho, que calor, que horas sãol posso ouvir a pivetada gritando lá foral hoje acordei cedo pra ver/ sentir a brisa da manhã e o sol nascer./ É época de pipa, o céu tá cheiol quinze anos atrás eu tava ali no meio./ Lembrei de quando era pequeno, eu e os caras./ faz tempo - diz aí! - o tempo não pára...

Brown, Fórmula mágica da paz

Este trecho, quase no final de a "Fórmula mágica da paz", é dos poucos - senão o único - em que o rap dos Racionais permite alguma sublimação dos sentidos, algum sentimento de elevação ou de alegria. Afinal, não é isto que o "ritmo e poesia" deveriam nos proporcionar?

Mas não. Nenhuma exaltação, nenhuma referência sublime é possível a uma arte que tem por principal função tentar simbolizar um cotidiano que se depara todo o tempo com o nó duro do real, no sentido que a psicanálise lacaniana atribui à palavra: o indizível, o que está além da capacidade de elaboração pela linguagem, o que nos escapa sempre.

O real domina a vida da periferia. É disto que falam os versos de Mano Brown e Edy Rock. São os últimos pensamentos de um homem que acaba de ser baleado, depois de seguir a carreira de um amigo no crime e ter sido acusado, pelo resto do bando, de entregá-lo à polícia. ${ }^{2}$ É o último dia na vida de um ex-presidiário que tenta se readaptar e criar o filho dignamente, mas acaba sendo acusado injustamente de um roubo nas redondezas e é executado pela polícia que invade sua casa na madrugada. ${ }^{3}$

É a história de um mano gente fina: "Você viu aquele mano na porta do bar? jogando bilhar, descontraído e pá/ cercado de uma pá de camaradas/ da área uma das pessoas mais consideradas/ ele não deixa brecha, não fode ninguém/ adianta vários lados sem olhar pra quem/ tem poucos bens, mais que nada/ um fusca 73 e uma mina apaixonada"... ("Mano na porta do bar" - Brown e Rock. Citada na p.7). Mas que começa a mudar, cercar-se de "tipos estranhos" que lhe prometem "o mundo dos sonhos"; o mano entrou no tráfico, matou a sangue-frio, "usou e viciou a molecada daqui" e tem o fim previsível: "Você tá vendo o movimento na porta do bar? / tem muita gente indo pra lá, o que será? (...) Você viu aquele mano na porta do bar? Ontem o cara caiu com uma rajada nas costas..."

O real domina a vida da periferia, em suas faces extremas: a droga e seu gozo mortífero; a violência do outro - freqüentemente a polícia $-{ }^{4}$ com quem é impossível qualquer diálogo, qualquer negociação; a miséria, que segundo Hanna Arendt nos exclue da condição humana porque nos faz prisioneiros da necessidade; e acima de tudo, a morte. O real se manifesta na figura do destino inexorável: hoje a pivetada vai para a escola, empina pipas na rua, joga bola - logo mais estarão traficando, viciados no crack, a caminho da morte certa. As letras de Brown e Edy Rock falam de um verdadeiro extermínio dos jovens de periferia; como acontece com os relatos dos sobreviventes dos campos de concentração, não há lugar para o sublime aqui.

Também não há muito lugar para o prazer, a alegria, a brincadeira. A droga e o álcool oferecem uma possibilidade de gozo. Os sonhos de consumo, de apropriar-se dos fetiches burgueses, "moto nervosa/ roupa da moda/ mina da hora", parecem oferecer um certo semblant de felicidade (assim como para os consumidores ricos, aliás), mas ficam inacessíveis a não ser que o cara enverede pelo crime. Não há beleza na paisagem da periferia. Nada de sombra e água fresca; nada de "área de lazer" - "Aqui não vejo nenhum centro poliesportivo/ pra molecada freqüentar nenhum incentivo/ o investimento no lazer é muito escasso/ o centro comunitário é um fracasso/ mas se quiser se destruir está no lugar certo/ tem bebida e cocaína sempre por perto"... ("Fim de semana no parque" - Brown e Rock). A inveja da vida dos ricos, dos bairros burgueses, dos privilégios, é inevitável: "Olha só aquele clube, que da hora/ olha aquela quadra, aquele campo, olha/ quanta gente/ tem sorveteria, cinema, piscina quente/ olha quanto boy, olha quanta mina/ afoga aquela vaca dentro da piscina/ tem corrida de kart, dá pra ver/ é igualzinho ao que eu vi ontem na TV./ Olha só aquele clube, que da hora/ olha o pretinho vendo tudo do lado de fora"...

Apesar desta inveja, os manos tentam afirmar sua diferença. A periferia que se valorize; os negros que tratem de bancar sua cultura, seus valores - este é o antídoto contra a alienação, contra a sedução promovida pela propaganda, pela tevê, arautos da sociedade de consumo. "Na periferia a alegria é igual/ é quase meio dia a euforia é geral/ é lá que moram meus irmãos, meus amigos/ e a maioria aqui se parece comigo./ E eu também sou o bambam-bam e o que manda/ o pessoal desde as 10 da manhã 
está no samba/ preste atenção no repique, atenção no acorde..."("Fim de semana...").

O real é a matéria bruta do dia-a-dia da periferia, é a matéria a ser simbolizada nas letras do rap. Uma tarefa que, como todo trabalho de simbolização, depende de um trabalho de criação de linguagem que só pode ser coletivo. É como se os poetas do rap fossem as caixas de ressonância, para o mundo, de uma língua que se reinventa diariamente para enfrentar o real da morte e da miséria; por isso eles não deixam a favela, não negam a origem. "Essa porra é um campo minado/ quantas vezes eu pensei em me jogar daqui/ mas aí, minha área é tudo o que eu tenho/ a minha vida é aqui e eu não consigo sair/ é muito fácil fugir, mas eu não vou/ não vou trair quem eu fui, quem eu sou" ("Fórmula mágica da paz" - Brown).

Este sentimento de pertinência e de dívida simbólica para com a origem e o semelhante lembram a diferença estabelecida por Alain Renault entre indivíduo e sujeito. O primeiro, tributário do ideal individualista de independência - centramento em si mesmo, negação da dívida, valorização narcísica do $e u$; o segundo, herdeiro do princípio humanista de autonomia - emancipação em relação a qualquer autoridade divina, transcendente, mas reconhecimento do laço social como fundamento do que é propriamente humano em cada um. Sujeitos autônomos, e não indivíduos independentes, os manos apelam a seus semelhantes para refazer o assassinato do pai abusivo, opressor, e recriar uma lei que proteja a todos do desamparo, que permita alguma alternativa ao real.

Enquanto isso, alguns raros momentos de contemplação são contrabandeados pelas brechas de uma vida que não oferece nada de graça. Acordar cedo, sentir a brisa, ver o sol nascer. O céu está cheio de pipas: como uma madeleine dos pobres, a visão dos quadradinhos coloridos lá no alto evoca a infância, o tempo perdido, a inocência que ficou para trás.

Mas as pipas são também a criação de um espaço virtual para a beleza, neste "campo minado" sem pontos de luz. As pipas obrigam o olhar a se manter acima da miséria, na direção de um céu que não é o céu da morte, de Deus e das almas; é o céu dos vivos. O céu que as crianças enfeitam com poucos recursos, cola, papel-de-seda e linha; céu da linguagem, céu humano. O céu cheio de pipas da periferia é uma interferência estética sobre a miséria e a recusa da desumanização que ela promove. Como a música, que só precisa das ondas do ar para existir e repercutir, como os versos quilométricos do rap, as pipas da molecada representam a ultrapassagem do reino da necessidade e do puro tempo imediato, sem passado e sem futuro, a que a necessidade nos reduz. No poema de Brown, o céu cheio de pipas surge como evocação da infância e projeção para um tempo futuro ("diz aí! - o tempo não pára"), um "fora daqui/aqui mesmo", um real tornado manso pela força da cultura.

Mas é no tempo presente, saindo do barraco para sentir a brisa da manhã, que o poeta/narrador de "Fórmula mágica..." obtém sua rápida epifania, seu curto instante de contemplação. A beleza, como se sabe, não exige grandes pompas para exercer seu poder transtornador; razão pela qual, apesar das diferenças de escolaridade, existem tantos poetas na periferia quanto em qualquer outro lugar. Termino propondo uma ponte, tão arbitrária quanto uma associação livre pode ser, entre a poesia de Brown e a prosa de Jean Genet, seu primo distante, numa das muitas passagens do Diário de um ladrão em que este escritor surpreendente estabelece uma relação entre a criação estética e uma atitude moral:

"A emoção muito especial que, ao acaso, chamei de poética, deixava em minha alma uma espécie de rastro de intranqüilidade que ia se atenuando. O murmúrio de uma voz, de noite, e no mar o barulho de remos invisíveis, naquela situação estranha, me haviam transtornado. Conservei-me atento para agarrar esses instantes que, errantes, me pareciam estar à procura de um corpo, uma alma penada, de uma consciência que os anote e os experimente. Quando o encontram, param: o poeta esgota o mundo. Mas, se ele propõe outro, só pode ser da sua própria reflexão. Quando, na Santé, comecei a escrever, nunca foi com o intuito de reviver minhas emoções ou de comunicálas, mas para que, da expressão delas imposta por elas, eu compusesse uma ordem (moral) desconhecida (de mim mesmo, em primeiro lugar)" (Genet, 1983:163).

É possível se concordar com Genet, quando ele afirma que a emoção estética produz uma ordem moral? O rap seria moral só por fazer "ritmo e poesia", independente do conteúdo ideológico de sua pregação? Talvez sim, nos casos em que a emoção estética seja capaz de produzir uma fala nova e promover uma experiência, "desconhecida de mim mesmo em primeiro lugar", isto é: revelar uma dimensão oculta do sujeito para ele mesmo e propor outro mundo (Genet), que "só pode ser o da sua própria reflexão". Ética e estética podem coincidir quando esta última tiver o poder de abrir uma brecha na pedra dura do real, adiando temporariamente nosso confronto inevitável com a morte. 


\section{FÓRMULA MÁGICA DA PAZ Mano Brown}

Essa porra é um campo minado

Quantas vezes eu pensei em me jogar daqui

mas aí, minha área é tudo que eu tenho

a minha vida é aqui e eu não consigo sair,

é muito fácil fugir mas eu não vou, não vou trair quem eu fui e quem eu sou.

Gosto de onde estou e de onde eu vim, ensinamento da favela foi muito bom pra mim. Cada lugar é um lugar, cada lugar uma lei, cada lei uma razão e eu sempre respeitei.

Qualquer jurisdição, qualquer área,

Jardim Santo Eduardo, Grajaú, Missionária

Funxal, Pedreira e tal, Joaniza

eu tento adivinhar o que você mais precisa.

Levantar sua goma ou comprar uns panos

um advogado pra tirar seu mano.

No dia da visita você diz

que eu vou mandar cigarro pros malucos lá no $\mathrm{X}$.

Então como eu estava dizendo, sangue bom,

isso não é sermão, ouve aí, eu tenho o dom.

Eu sei como é que é, é foda parceiro

é a maldade na cabeça o dia inteiro.

Nada de roupa, nada de carro, sem emprego

não tem Ibope, não tem rolê, sem dinheiro.

Sendo assim, sem chance, sem mulher,

você sabe muito bem o que ela quer,

encontre uma de caráter se você puder,

é embaçado ou não é,

ninguém é mais que ninguém, absolutamente, aqui quem fala é mais um sobrevivente.

Eu era só um moleque, só pensava em dançar,

cabelo black e tênis All Star.

Na roda da função mó zoeira,

tomando vinho seco em volta da fogueira,

a noite toda e só contando história,

sobre o crime, sobre as tretas da escola.

Não tava nem aí, nem levava nada a sério

admirava os ladrão e os malandro mais velho, mas se liga, olhe ao seu redor e me diga,

o que melhorou da função, quem sobrou, sei lá,

muito velório rolou de lá pra cá,

qual a próxima mãe que vai chorar,

já demorou muito mais hoje eu posso compreender

que malandragem de verdade é viver.

Agradeço a Deus e aos Orixás,

parei no meio do caminho e olhei prá trás.

Meus outros manos todos foram longe demais:

Cemitério São Luís aqui jaz.
Mas que merda meu oitão tá até a boca,

que vida louca, porque é que tem que ser assim,

ontem sonhei que um fulano se aproximou de mim,

agora eu quero ver, ladrão, pá.pá.pá,

fim; é sonho, é sonho, deixa quieto,

sexto sentido é um dom, eu tô esperto.

Morrer é um fator, mas conforme for,

tem no bolso uma agulha e mais cinco no tambor.

Vai, joga o jogo, vamos lá,

pá, caiu a 8 eu mato a par

eu não preciso muito pra me sentir capaz

de encontrar a Fórmula Mágica da Paz.

(Refrão) Eu vou procurar, sei que vou encontrar, eu vou procurar, eu vou procurar,

você não bota uma fé mas eu sei que vou atrás

da minha Fórmula Mágica da Paz.

Caralho, que calor, que horas são,

posso ouvir a pivetada gritando lá fora.

Hoje acordei cedo pra ver,

sentir a brisa de manhã e o sol nascer.

É época de pipa, o céu tá cheio,

quinze anos atrás eu tava ali no meio,

lembrei de quando era pequeno,

eu e os cara; faz tempo, diz aí, o tempo não pára.

Hoje tá da hora o esquema prá sair,

mano não demora, mano chega aí,

cê ouviu os tiro? ouvi de monte, então:

diz que tem uma pá de sangue no campão.

Ih, mano, toda mão é sempre a mesma idéia junto,

treta, tiro, sangue, aí! muda de assunto!

traz a fita pra eu ouvir porque eu tô sem,

principalmente aquela lá do Jorge Ben.

Uma pá de mano preso chora a solidão,

uma pá de mano solto sem disposição,

penhorando por aí,

rádio, tênis, calça, acende num cachimbo, virou fumaça.

Não é por nada não, mas aí, nem me ligo a hora,

a minha liberdade eu curto bem melhor,

eu não estou nem aí pro que os outros fala,

quatro, cinco, seis pretos num Opala.

Pode vir, gambé, paga pau, tô na minha moral na maior, sem goró, sem pacau, sem pó, eu tô ligeiro

eu tenho a minha regra, não sou pedreiro, não fumo pedra. Um rolê com os aliados já me faz feliz, respeito mútuo é a chave do que eu sempre quis, me diz, procure a sua, a minha eu vou atrás, até mais, na Fórmula Mágica da Paz.

Refrão: Eu vou procurar...etc. 
Choro e correria num saguão de hospital, dia das crianças, feriado indo pro final, sangue e agonia entram pelo corredor; - ele está vivo? pelo amor de Deus, doutor! Quatro tiros do pescoço pra cima, puta que pariu, a chance é mínima. Aqui fora revolta e dor, lá dentro estado desesperador. Eu percebi quem eu sou realmente, quando ouvi o meu subconsciente: aí, Mano Brown cuzão, cadê você, seu mano tá morrendo, o que você vai fazer? pode crê, eu me senti inútil, me senti pequeno, mais um cuzão vingativo, vai vendo. Puta desespero, não dá pra acreditar, que pesadelo, eu quero acordar, não dá, não deu, não daria de jeito nenhum, o Delei era só mais um rapaz comum.

Daqui a poucos minutos, mais uma dona Maria de luto. Na parede o sinal da cruz, que porra é essa? que mundo é esse? onde está Jesus? Mais uma vez um emissário não incluiu o Capão Redondo em seu itinerário. Corro, eu tô confuso, preciso pensar me dá um tempo pra eu raciocinar, eu já não sei distinguir quem tá errado, sei lá, minha ideologia enfraqueceu, preto, branco, polícia, ladrão ou eu, quem é mais filha da puta eu não sei, aí fodeu, fodeu, decepção nessas horas,

a depressão quer me pegar, vou sair fora.

Dois de novembro era Finados, eu parei em frente ao São Luís do outro lado e durante meia hora eu olhei um por um, e o que todas as senhoras tinham em comum: a roupa humilde, a pele escura, o rosto abatido pela vida dura, colocando flores sobre a sepultura, podia ser minha mãe, que loucura. Cada lugar uma lei, eu tô ligado, no extremo sul da Zona Sul tá tudo errado, aqui vale muito pouco a sua vida, a nossa lei é falha é violenta é suicida, se diz que me diz que, não se revela, parada pro primeiro na lei da favela, legal, assustador é quando você descobre que tudo deu em nada e que só morre o pobre. A gente vive se matando, irmão, por quê? não me olhe assim, eu sou igual a você, descanse o seu gatilho, descanse o seu gatilho porque no trem da malandragem meu Rap é o trilho.

\section{NOTAS}

Ao Luan, que me apresentou os Racionais $M C$ 's.

1. Veja-se a respeito o artigo de Contardo Calligaris (1991).

2. "Tô ouvindo alguém me chamar" (Mano Brown) - "Tô ouvindo alguém gritar meu nome/ parece um mano meu, é voz de homem/ eu não consigo ver quem me chama/ é tipo a voz do Guima/ não, não, o Guima tá em cana/ Será? ouvi dizer que morreu, não sei. (...) Parceria forte aqui era nós dois./ Louco, louco, louco e como era/ cheirava pra caralho, vixe! sem miséria!/ todo ponta firme/ foi professor no crime/ também, maior sangue frio, não dava boi pra ninguém!/ Puta, aquele mano era foda!/ só moto nervosa/ só mina da hora/ só roupa da moda"...

3. "O homem na estrada"(Mano Brown) - "O homem na estrada recomeça sua vida/ sua finalidade, a sua liberdade, que foi perdida,/ subtraída/ e quer provar a si mesmo que realmente mudou/ que se recuperou, que quer viver em paz/ não olhar prá trás, dizer ao crime nunca mais/ pois sua infância não foi um mar de rosas não/ na Febem, lembranças dolorosas então (...) Equilibrado num barraco incômodo, mal acabado e sujo/ porém seu único lar, seu bem e seu refúgio/ cheiro horrível de esgoto no quintal/ por cima ou por baixo, se chover será fatal/ um pedaço do inferno aqui é onde estou..."

4. "Não confio na polícia, raça do caralho!/ se eles me acham baleado na calçada/ chutam minha cara e cospem em mim/ e eu sangraria até a morte, já era, um abraço/ por isso minha segurança eu mesmo faço" ("Homem na estrada" - Mano Brown).

\section{REFERÊNCIAS BIBLIOGRÁFICAS}

BARTHES, R. "O mito como linguagem roubada". In: Mitologias. São Paulo, Difel, 1975, p.152-158.

CALLIGARIS, C. "Função paterna". In: Hello Brasil. São Paulo, Escuta, 1991, p.59-81.

DOR, J. O pai e sua função em psicanálise. Rio de Janeiro, Zahar, 1985.

FREUD, S. "Totem y Tabu". In: Obras Completas, v.II. Madri, Biblioteca Nueva, 1976.

GENET, J. Diário de um ladrão. Rio de Janeiro, Nova Fronteira, 1983.

KEHL, M.R. A mínima diferença. Rio de Janeiro, Ed. Imago, 1996. 1996. Processos primários (poemas). São Paulo, Estação Liberdade, Deslocamentos do feminino. Rio de Janeiro, Ed. Imago, 1998.

RANCIÈRE, J. Políticas da escrita. Rio de Janeiro, Editora 34, 1999.

RENAULT, A. O indivíduo. São Paulo, Difel, 1998. 